\title{
Examination of the Machinability of Eutectic Aluminium Alloys
}

Richard Horvath ${ }^{1}$, Gyula Matyasi ${ }^{2}$, Agota Dregelyi-Kiss ${ }^{1}$

${ }^{1}$ Obuda University Donat Banki Faculty of Mechanical and Safety Engineering, Budapest, H-1081, 8 Nepszinház Street, Hungary, e-mail: horvath.richard@bgk.uni-obuda.hu,dregelyi.agota@bgk.uni-obuda.hu

${ }^{2}$ Budapest University of Technology and Economics, Budapest, H-1111 1 Egry József Street, Hungary, e-mail: matyasi@manuf.bme.hu

The industrial use of aluminium alloys has significantly increased in the last decades. Most machined parts are produced by cutting. Therefore, research in this field is quite important nowadays. Surface roughness is an extremely important quality parameter of a product, such as geometrical sizes and their tolerance. The authors in this article analysed the machinability of die-cast aluminium alloys with silicon often used in the industry. The turning experiments were made with different diamond tools edge geometry. The surface roughness obtained during turning was analysed in detail. Phenomenological models were created with which the surface roughness producing ability of the examined tools can be estimated in technological design.

Keywords: aluminium fine turning, eutectic aluminium alloy, design of experiment, surface roughness, phenomenological model

\section{References}

[1] KUNDRÁK, J. (2011). Alternative machining procedures of hardened steels, Manufacturing Technology, 11, pp. 32-39.

[2] KUNDRÁK, J., GYÁNI, K., DESZPOTH, I. (2012). The effect of the borehole diameter on the machining times in hard machining, Manufacturing Technology, 13, pp. 144-150

[3] SZTANKOVICS, I., KUNDRÁK, J. (2013). Theoretical Value of Total Height of Profile in Rotational Turning. Applied Mechanics and Materials, Vol. 309, pp. 154-161.

[4] MIKÓ, B., BENO, J., MANKOVA, I. (2012), Experimental verification of cusp heights when 3D milling rounded surfaces, Acta Polytechnica Hungarica Vol. 9 No (6), pp. 101-116.

[5] FELHÖ, CS., KUNDRÁK, J. (2014), Comparison of Theoretical and Real Surface Roughness in Face Milling with Octogonal and Circural Inserts, Key Engineering Materials, Vol. 581, pp. 360-365. Trans Tech Publications, Switzerland

[6] DABNUN, M. A., HASHMI, M.S.J., EL-BARADIE, M.A. (2005). Surface roughness prediction model by design of experiments for turning machinable glass-ceramic (Macor). Journal of Materials Processing Technology, 164165 pp. $1289-1293$.

[7] DAVIM, J. P. (2003). Design of optimisation of cutting parameters for turning metal matrix composites based on the ortogonal arrays. Journal of Materials Processing Technology, 132 pp. 340-344.

[8] SZALÓKI, I., CSUKA, S., SIPOS, S. (2014). New Test Results in Cycloid-Forming Trochoidal Milling. Acta Polytechnica Hungarica Vol. 11, No. 2, pp. 215 - 228.

[9] KAÇAL, A., YILDIRIM, F. (2013). High Speed Hard Turning of AISI S1 (60WCrV8) Cold Work Tool Steel. Acta Polytechnica Hungarica Vol. 10, No. 8, 2013, pp. 169 - 186.

[10]KUNDRÁK, J., PÁLMAI, Z. (2014). Application of general tool-life function under changing cutting conditions, Acta Polytechnica Hungarica Vol. 11 No(2), pp. 61-76.

[11]KUNDRÁK, J., GYÁNI, K., BANA, V. (2008). Roughness of ground and hard-turned surfaces on the basis of 3D parameters, The International Journal of Advanced Manufacturing Technology. 38, pp. 110-119.

[12]TUKORA, B., SZALAY, T. (2012). Multi-dexelbasedmaterialremovalsimulation and cuttingforce prediction with the use of general-purpose graphics processing units, Advances in Engineering Software 43, pp. 65-70.

[13]SZALAY, T., ALPEK, F., MONOSTORI, L., MARKOS, S., VIHAROS, ZS. (1996). Investigation of machined surfaces using artificial intelligence methods, In: $9^{\text {th }}$ international conference on tools. Miskolc, Hungary, 03 - 05 September 1996, pp. 635-640.

[14]SZALAY, T., MARKOS, S., MÉSZÁROS, I. (1995). Monitoring of the cutting operations using fuzzy logic, In: $8^{\text {th }}$ international conference of AIIEAE. Melbourne, Australia, 06 - 08 Juni 1995, pp. 27-30. 
[15]DRÉGELYI-KISS, Á., HORVÁTH, R., MIKÓ, B. (2012). Design of experiments (DOE) in investigation of cutting technologies. Development in Machining Technology/Scientific-Research Reports, vol.3, pp. 20 - 34. (Book chapter) Krakow University.

[16]HORVÁTH R., DRÉGELYI-KISS, Á. (2013). Analysis of surface roughness parameters in aluminium fine turning with diamond tool. Measurement 2013 Conference, Smolenice, Slovakia, pp. 275-278.

[17]HORVÁTH, R., DRÉGELYI-KISS, Á., MÁTYÁSI, GY. (2014). Application of RSM method for the examination of diamond tools. Acta Polytechnica Hungarica Vol. 11, No. 2, pp.137 - 147.

[18]POKORÁDI, L. (2008). Systems and Processes Modeling, Campus Kiadó, Debrecen. pp. 242. (in Hungarian)

[19]POKORÁDI, L. (2009). Uncertainties of Mathematical Modeling, Proc. of the $12^{\text {th }}$ Symposium of Mathematics and its Applications. Timisoara, Romania, 05 - 07 November 2009, pp. 471-476.

[20]ROUTARA, B.C., BANDYOPADHYAY, A., SAHOO, P. (2009). Roughness modeling and optimization in CNC end milling using response surface method: effect of workpiece material variation, The International Journal of Advanced Manufacturing Technology, 40. pp. 1166-1180.

[21] GRZESIK, W., WANAT, T. (2006). Surface finish generated in hard turning of quenched alloy steel parts using conventional and wiper ceramic inserts. International Journal of Machine Tools \& Manufacture, 46, pp. 19881995. 